\title{
Chapter 11 \\ The Role of the Physical Sciences in Loss and Damage Decision-Making
}

\author{
Ana Lopez, Swenja Surminski and Olivia Serdeczny
}

\begin{abstract}
This chapter reviews the implications of Loss and Damage (L\&D) for decision-making with a special focus on the role of the physical sciences for decision support. From the point of view of climate science, the question regarding the estimation of losses and damages associated with climate change can be thought of in terms of two temporal scales: the present and the future. In both cases the aim is to establish the links between human-induced changes in climate and climate variability, the probability of occurrence of extreme meteorological events (e.g., rainfall), and the resulting hazard that causes losses and damages (e.g., flood). We review the approaches used to assess the hazard component of risk, with a special emphasis on identifying sources of uncertainty and the potential for providing robust information to support decision-making. We then discuss tools and approaches that have been developed in the context of Climate Change Adaptation (CCA) to deal with uncertainty from climate science in order to avoid a 'wait and see' mentality for decision-making. We argue that these can be applied to some parts of L\&D decisionmaking, in the same way as suggested for CCA, since the challenges presented by the need to reduce and manage climate change losses and damages are not very different from the ones presented by the need to adapt to climate change and variability. However additional challenges for decision-makers, particularly in the context of the underlying science, are posed by the compensation and burden-sharing components of L\&D for climate impacts that are beyond mitigation and adaptation's reach.
\end{abstract}

Keywords Loss and Damage $\cdot$ Climate decision-making $\cdot$ Uncertainty Climate change attribution

\footnotetext{
A. Lopez $(\varangle)$

Physics Department and University College, Oxford University, Oxford, UK e-mail: ana_lopez@fastmail.uk

S. Surminski

Grantham Research Institute on Climate Change and the Environment, London School of Economics and Political Science (LSE), London, UK

O. Serdeczny

Climate Analytics GmbH, Berlin, Germany

(C) The Author(s) 2019

R. Mechler et al. (eds.), Loss and Damage from Climate Change, Climate Risk

Management, Policy and Governance, https://doi.org/10.1007/978-3-319-72026-5_11
} 


\subsection{Introduction}

Article 8 of the Paris Agreement calls for action on 'averting, minimising and addressing Loss and Damage associated with the adverse effects of climate change, including extreme weather events and slow onset events.' In response, decisions need to be made - on a wide range of topics and at various levels of governance ranging from the global level, where UNFCCC negotiators need to decide how to take this topic forward, how to allocate funding and to establish possible institutional frameworks around Loss and Damage (L\&D), all the way through to the local level, where communities need to understand and manage changing risks.

Despite significant progress in scientific understanding and methodological advances, decision makers face key constraints when making those decisions: limited data, uncertainty about climatic and socio-economic trends, and the complex interplay between climate and human behaviour may seem as insurmountable and lead to inactivity if not addressed properly.

These challenges are well known to those tasked with climate change adaptation and disaster risk management (Watkiss 2015), and a range of decision-support tools have been developed in response. However, assessing and addressing L\&D suffers from a further level of complexity: it is a politically charged concept, with blurred conceptual boundaries (e.g., where do climate change adaptation efforts stop and where does the L\&D remit start?) and a moral and ethical dimension (see introduction by Mechler et al. 2018; chapters by Wallimann-Helmer et al. 2018; Schinko et al. 2018; James et al. 2018; Botzen et al. 2018 in this book).

The L\&D of climate change officially entered the UNFCCC discussions in 2007, but the concept itself has a far longer history. Growing awareness of the projected negative impacts of climate change has been at the core of the emerging mitigation and adaptation efforts. In the early adaptation literature, there was reference to the residual impacts after mitigation and adaptation were carried out. In this context, the idea of L\&D associated with extreme events appeared as a consequence of the limits to current levels of adaptation (Smit et al. 2000; Smithers and Smit 1997).

While L\&D under the UNFCCC is foremost a political concept determined by legal considerations around climate change, the technical dimension of L\&D has its roots in the general risk management methodology, based on a terminology widely applied originally in Disaster Risk Reduction (DRR) and later on in Climate Change Adaptation (CCA). UNFCCC (2012a) explores the terminology in detail—highlighting different approaches to L\&D as currently applied to DRR and CCA. Most broadly, 'damage' is seen as the physical impact and 'loss' as monetized values, which could be direct or indirect (economic follow on effects) (UNFCCC 2012a). Here the focus is on categorising, assessing and projecting impacts of events-mainly in the context of disasters, but also in the context of climate change implications for sudden-onset and slow-onset impacts, over a range of time-scales, and including direct and indirect economic losses, as well as so-called non-economic losses such as losses of lives and of eco-system services. In the broader climate change context L\&D is often described as the third cost element of climate change, as outlined by Klein et al. (2007) (see 
also van Vuuren et al. 2011): mitigation costs, adaptation costs and residual damage. In this context addressing L\&D is seen as addressing those losses that are likely to occur despite adaptation and mitigation efforts.

This academic exercise of framing L\&D (see also chapters by Mechler et al. 2018 and James et al. 2018 in this book) is replicated amongst policy makers-where different interpretations of scope and concept are apparent amongst UNFCCC Parties, as highlighted by Kreft (2012): "Some Parties suggest that L\&D is the residual risk when mitigation is insufficient, and when the full potential of adaptation is not met (Norway) while others frame L\&D as the residual losses and damages after mitigation and adaptation choices have been made (Gambia). Ghana proposes that the concept of Loss and Damage from the adverse effects of climate be viewed as additional to adaptation focusing on challenges of both identifying and addressing the instances when adaptation is no longer possible. However, Bolivia maintains that Loss and Damage from the adverse effects of climate change concept is beyond adaptation, and as such is additional to adaptation, focusing on challenges of both identifying and addressing the instances when adaptation is no longer possible" (Kreft 2012).

This discourse highlights that stakeholders have different priorities and ambitions for action on L\&D. Those can be broadly summarised in three categories of decision goals for L\&D (Surminski and Lopez 2014):

- To create awareness about the sensitivity of human and natural systems to climate and the need to respond with appropriate mitigation, adaptation and DRR policies (UNFCCC 2012b).

- To develop risk reduction and risk management responses, with the goal to enhance adaptation to reduce vulnerability and build resilience; in this case the evaluation of climate risk is a necessary component of any adaptation options appraisal. This category has many analogies with CCA and DRR, addressing the assessment of and response to risks.

- To inform discussions on fair burden-sharing and compensation arrangements for L\&D. While discussions around compensation underlined debates on L\&D particularly in their beginning, they have lost immediate relevance in the official discussions since the Paris decision that stated that L\&D would not provide a basis for compensation or liability.

In this chapter we consider how climate science can support those three goals and how uncertainties and limitations arising from the analysis of the climate hazard affect L\&D decision-making. In particular, we discuss the role that existing approaches to decision making could play when addressing each of the policy goals embedded in the climate change L\&D discussion. We conclude with a commentary and outlook for the on-going discussions about L\&D. 


\subsection{L\&D from a Physical Science Point of View-The Challenges of Assessing the Risk}

Risk is a function of hazard, exposure and vulnerability. Therefore, any attempt of assessing the risk of losses and damages from climate change needs to incorporate two key components and illustrate their interplay: data on vulnerability and exposure, as well as information on the climatic hazard, including current climatic variability and future, long-term projections of climate change (UNFCCC 2008, 2012a). From a physical science perspective the focus is traditionally on the hazard side of risks, but there is a clear recognition that data needs and limitations for vulnerability and exposure assessments are equally important for understanding climate change risks.

The information about the climate hazard ${ }^{1}$ relates to the physical phenomena, such as large cyclonic storms or long-term reductions in precipitation, and their consequences, such as flooding or drought. This hazard information contains the input to estimate the magnitude and frequency of damaging meteorological events in DRR approaches, or to project changes in climate risks to inform CCA. From the physical sciences point of view, there are challenges to estimate the hazard part of the total risk common to all interpretations of L\&D.

IPCC's SREX concluded with high confidence that increasing exposure of people and economic assets has been the major cause of long-term increases in economic losses from weather- and climate-related disasters, arguing that the development pathways of a country or community do influence exposure and vulnerability (IPCC 2012). But understanding the 'multi-faceted nature' (IPCC 2012) of both exposure and vulnerability is still a challenge, due to data limitations and the inherent uncertainty in socio-economic trends (GAR 2011). The data required for assessing vulnerability and exposure varies, depending on scope and context. It can include historical loss information, property databases, demographic data, macroeconomic data such as debt and fiscal budgets (UNFCCC 2012a). In addition there are the intangibility aspects of $L \& D$, which are not valued by markets and therefore are often left out of any assessments. The ability to capture direct and indirect losses is also identified as a key challenge as highlighted at the 36th Subsidiary Body for Implementation meeting in May 2012, where it was noted that available estimates on losses typically lack numbers on non-economic losses such as culture and heritage (UNFCCC 2012b). Government asset databases or sectorial disaster loss data are not available in all countries, or they may be very limited in scope, not capturing those intangible impacts (Mechler et al. 2009). This makes assumptions and extrapolations necessary, which add to the degree of uncertainty for L\&D assessments. The chapter by Bouwer (2018) in this book discusses in more detail the interplay between exposure and vulnerability and observed and expected losses due to anthropogenic climate change.

\footnotetext{
${ }^{1}$ We note that, while the IPCC AR5 refers to 'physical impacts' as the impacts of climate change on geophysical systems, including floods, droughts, and sea level rise, we use the term 'hazard' instead to refer to the physical impacts.
} 
To evaluate the current and changing likelihood of climatic hazards different sources of information are employed (IPCC 2012, 2013, 2014a, b). Historical records of climate variables, such as temperature or precipitation, are used to estimate the hazard probability under historical climatic conditions. Climate models are used to estimate changes of these variables in the future under different scenarios of greenhouse gasses' emissions or concentrations. Hazard and impact models are then employed to evaluate how changes in climatic variables will produce changes in natural or human systems, e.g., how changes in precipitation patterns will affect flood regimes in a given catchment.

In the rest of this section we briefly describe the information and tools utilised to estimate the current observed hazard probability and its projected changes.

\subsubsection{Observed Hazard}

Historical records of climate variables must be accurate, representative, homogeneous and of sufficient length if they are to provide robust estimates of current hazard probability. The robustness of the inferred probabilities depends for instance on the record length; short records of precipitation in a particular location do not provide enough information about the extreme precipitation events that might have occurred in the past. Poor quality of data (incorrect records or missing data) can induce large uncertainties in the estimation of current climatic hazards. While data for temperature and precipitation is more widely available, other variables such as soil moisture are poorly monitored, or extreme wind speeds are not monitored with sufficient spatial resolution.

Paleoclimatology can provide information about rare, large magnitude hydrometeorological events in places where long enough observational records are not available and good proxies to estimate the magnitude of past events such as floods or droughts can be found. For instance, instrumental records of floods at gauge stations are limited in spatial coverage and time, with only a small number of gauge stations spanning more than 50 years. Pre-instrumental flood data can provide information for longer periods, however the current availability of this data is scarce particularly in spatial coverage (IPCC 2012). Paleoclimate data can then provide information about a range of climate hazards that have occurred in the remote past, often illustrating the fact that, in many cases, the recent observational records provide very limited information about the range of the unforced natural variability in a particular location (Benito et al. 2004; IPCC 2012). However, paleoclimatology can only provide information in cases where adequate proxies exist, as for instance tree-ring temperature and rainfall reconstructions, paleo coastal surges, etc.; but it is not a viable option for some other variables such as high resolution wind speed. 


\subsubsection{Projected Changes in Hazard}

Projections of changes in future climate are generally derived using General Circulation Models (GCMs) which simulate the response of the climate system to a scenario of future emissions or concentrations of greenhouse gases and aerosols. Even though the physical and chemical processes in the climate system follow known physical laws, its complexity implies that many simplifications and approximations have to be made when modelling them. The choice of approximations creates a variety of physical climate models (IPCC 2013).

There are different sources of uncertainties in climate model simulations, including (anthropogenic and natural) forcing, initial conditions, and model imperfections (both model uncertainty and model inadequacy) (Stainforth et al. 2007). Climate forcing or scenario uncertainty is introduced by the fact that, to simulate future climate, the models are run using different scenarios of anthropogenic forcings that either represent plausible but inherently unknowable future socioeconomic development ${ }^{2}$ or could arise as the result of multiple pathways of socioeconomic development (Meinshausen et al. 2011). Climate model imperfections and initial conditions uncertainties are due to our incomplete knowledge of the climate system, the limitations of computer models to simulate it, and the system's non-linearity (Knutti et al. 2007; Stainforth et al. 2007). To quantify climate model uncertainty a variety of climate models have been developed around the world. For instance, the IPCC AR5 report (IPCC 2013) includes projections from 42 climate models.

The uncertainty in projections of future climate variability is quantified by constructing, for a given climate model, a set of projections that are initialised in slightly different ways (see for instance Deser et al. (2012a, b) for the effect of initialisation in long term projections for a single climate model, and Kirtman et al. (2013) for near term or decadal projections). For each possible forcing scenario, ensembles of different climate models that include various approaches to implementing the components of the climate system, and, within each model, different parameterisations and initialisations, are used to estimate the effect of climate model imperfections and initial conditions uncertainties in the projections of climate change.

The relative contributions to the total uncertainty from these different sources depend on the spatial scale, the lead-time of the projection, and the variable of interest. For instance for precipitation, at spatial scales of the order of $1000 \mathrm{~km}$, internal variability is the main source of uncertainty in climate model projections for many regions in the world for lead times up to three decades ahead, while forcing uncertainty dominates thereafter (Kirtman et al. 2013; Booth et al. 2013; Hawkins and Sutton 2009).

While GCMs simulate the entire Earth with a relatively coarse spatial resolution (e.g. they can capture features with scales of a hundred kilometres or larger), regional climate projections downscaled from GCMs have a much higher resolution

\footnotetext{
${ }^{2}$ This is the approach used prior to the IPCC AR5 report, see for instance IPCC (2000), Moss et al. (2008).
} 
(simulating features with scales as small as a few kilometres). Downscaling can be accomplished through one of two techniques: 'dynamical' or 'statistical' downscaling (Wilby et al. 2009). 'Dynamical' downscaling refers to the process of nesting high resolution Regional Climate Models (RCMs) within a global GCM (Hewitson et al. 2014; Giorgi et al. 2015) while 'statistical' downscaling relies on using statistical relationships between large-scale atmospheric variables and regional climate (often at meteorological station level) to generate projections of future local climatic conditions. Statistical methods may also include weather generators that simulate weather events and their extremes. Downscaling approaches do not provide magical fixes to possible limitations in the data being downscaled (Kerr 2011). In cases where the large scale GCM signal accurately represents the observed one, downscaling can add value by incorporating features that are absent in GCMs, such as the effect of coastlines and complex orography (Hall 2014). However, when for instance different RCMs driven by the same GCM show a wide range of responses in precipitation (Hewitson et al. 2014), the generation of climate projections using downscaling techniques will often increase the level of uncertainty in the original GCM projections, having significant effects in the estimation of probabilities of occurrence of damaging events in DRR models and climate change risk assessments.

Climate model projections (and their downscaled versions) provide information about climate variables such as temperature, precipitation, sea level, etc. The next step in a climate risk assessment involves understanding how changes in the climate variables will affect natural or human systems. Hazard models are computational models that take as inputs observed or simulated climate variables such as temperature, precipitation, soil moisture content, wind speed, etc., and use them to simulate the variables that are relevant to analyse a particular weather or climate hazard (IPCC 2012, 2014a, b). For instance, extreme rainfall events can cause floods. But to estimate the extent of the flooded area, hydrological and hydraulic models are used to generate the flood footprint for each particular event (Ranger et al. 2011; Jha et al. 2012). Some of the limitations of hazard models are similar to those of climate models: poor representation of the physical processes involved, calibration issues and computational constraints all contribute to compounding the uncertainties in the climate inputs with the uncertainties in the hazard model outputs. This is illustrated, for example, by multi-model assessments of water availability and flood potential, where a large ensemble of global hydrological models is forced by an ensemble of GCMs to estimate climate change impacts on water resources. These studies show that climate and hydrological models contribute to a similar extent to the spread in relative river flows' changes globally (Schewe et al. 2014; Dankers et al. 2014).

An alternative approach to estimate the physical impacts of climate change used when model projections are not available, is the use of 'analogies.' Two types of analogies are possible: spatial analogies whereby another part of the world experiencing similar conditions to those expected to occur in the future is used as a proxy to estimate future impacts in the region of interest; and temporal analogies whereby changes in the past (sometimes obtained from paleo-records) are used to make inferences about changes in the future. This approach has two limitations. Firstly, expert 
judgment is required to estimate the uncertainty of the projected impacts (Bos et al. 2015; IPCC 2014a, b). Secondly, the applicability of the approach depends on the climate variable and the location; for example Dahinden et al. (2017) show that it is often not possible to find analogues in temperature and precipitation simultaneously. The above discussion refers specifically to the estimation of the hazard component of risk. As already mentioned, the risk is, however, the probability of occurrence of the hazard multiplied by the impacts if these events occur. In the IPCC AR5 'climate change impacts' refer to "the effect on lives, livelihoods, health, ecosystems, economies, societies, cultures, services, and infrastructure due to the interaction of climate changes or hazardous climate events occurring within a specific time period and the vulnerability of an exposed society or system" (IPCC 2014a).

Therefore, the study of 'climate change impacts' requires impacts models that combine projections of climate change with socio-economic scenarios. To this end, the Inter-Sectorial Impact Model Intercomparison Project (ISI-MIP) aims to study the impacts of climate change on flood hazard, food and water availability, health, ecosystems and coastal infrastructure, together with their interactions and uncertainties in order to provide a comprehensive picture of climate change risks (see Schellnhuber et al. (2014) and references therein).

When considering the risk, including exposure and vulnerability, at shorter time scales, in many cases the current natural variability of the climate system and other non-climatic drivers of risks will have a higher impact than the climatic changes driven by changes in atmospheric concentrations of greenhouse gases. For example, in the near term, changes in exposure such as urbanization and building housing developments on flood-prone areas could increase significantly the risk of flooding and damage to the aforementioned infrastructure, independently of climate change. Over longer time scales, it is expected that anthropogenic climate change will often play a more significant role (Oppenheimer et al. 2014).

The above discussion about the estimation of the climate hazard is closely related to, and based on similar discussions in the context of CCA. However, L\&D also brings something distinctly unique to the discussion: embedded in the political concept of L\&D, at least according to some, is the element of burden sharing and compensation, which could require the estimation of the attributable fraction of losses and damages to human induced climate change. From the physical sciences point of view, and focusing on the question of attribution of the climate hazard or physical impact, it is clear that estimations of changes in its likelihood do not, a priori, have any information about whether or not the changing probability can be attributed ${ }^{3}$ to human induced climate change. Approaches that attempt to quantify the attributable component of the changes in the probability of occurrence of meteorological hazards rely heavily on climate models to compare the likelihood of the weather event with and without the influence of anthropogenic emissions of greenhouse gases. However, as already

\footnotetext{
${ }^{3}$ As defined by the IPCC, detection of climate change is the process of demonstrating that climate has changed in some defined statistical sense, without providing a reason for that change. Attribution of causes of climate change is the process of establishing the most likely causes for the detected change, either natural or anthropogenic, with some defined level of confidence (source: IPCC 2012).
} 


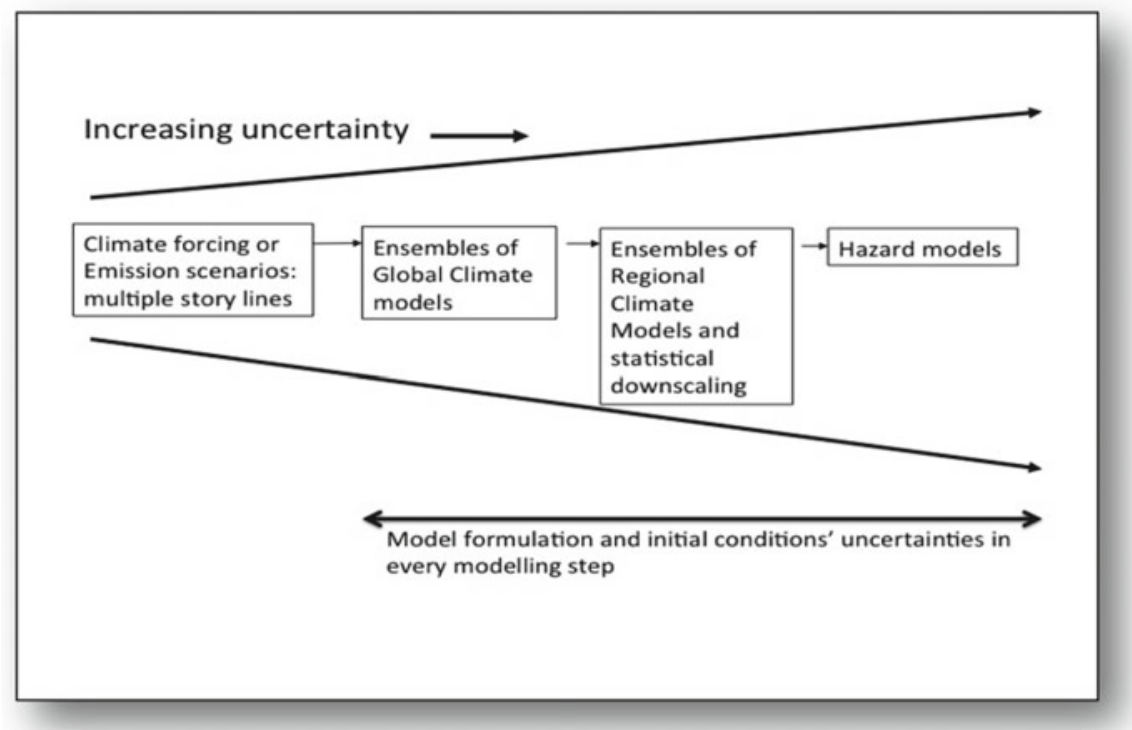

Fig. 11.1 The uncertainty cascade in the modelling chain from climate model forcings to the estimation of the climate hazard (the physical impact of climate change). An estimation of the total risk should include vulnerability and exposure scenarios that, in combination with the climate hazard as inputs for an impact model, outputs the total impact on, for instance, lives, livelihoods, health, ecosystems, economies, societies, cultures, services, and infrastructure

discussed, climate models have significant limitations to simulate the climate system at the scales relevant for extreme meteorological events (Trenberth 2012; Trenberth and Fasullo 2012). Therefore, an evaluation of the climate model skill (Stott et al. 2017) and the statistical reliability of the model-based probabilities (Bellprat and Doblas-Reyes 2016; Weisheimer et al. 2017) should be carried out to ensure robust estimates of attributable changes in climate hazards. For a detailed discussion on attribution we refer the reader to the chapter by James et al. (2018) in this book.

In summary, a comprehensive modelling approach to assess climate change induced hazards requires the combined simulation of all the domains. For flood risk, for instance, it requires the modelling of the atmosphere and ocean, catchment river network, flood plains and indirectly affected areas. As discussed above, and illustrated in Fig. 11.1, considerable uncertainty is introduced in each of the modelling steps involved, including uncertainties about the greenhouse gas concentrations' scenarios, the representation of physical processes in the global climate model, the characterisation of natural variability, the method of downscaling to catchment scales and the hydrological and inundation models' structures and parameterizations. 
As a result, the uncertainty associated with a complete modelling chain, from climate forcing and simulation to estimation of hazard probability, is likely to increase in each step, and become particularly large at local scales. In addition, uncertainty estimates are always conditional on the modelling approaches used to obtain them, and do not capture the full uncertainty (Smith and Stern 2011; Stainforth et al. 2007), especially at local scales, where current modelling tools to generate projections cannot produce reliable and robust estimates of future changes (Oreskes et al. 2010; Risbey and O'Kane 2011). This is particularly important in the case of catastrophic changes in the climate system that might occur due to non-linear feedbacks and processes that are not known, or have not been adequately incorporated in the climate models yet.

Nonetheless, the presence of uncertainties in the estimation of hazards, and the fact that in some cases these uncertainties might not decrease in time, ${ }^{4}$ should not stop decisions being made. In the next section we discuss some of the decision-making approaches utilised for CCA to deal specifically with this issue.

\subsection{Challenges for L\&D Decision-Making}

L\&D — both as a political concept but also in its technical dimension requires decisions to be made at different scales from local to global, and by a range of stakeholders with differing priorities and agendas. These can be broadly grouped into three categories of L\&D decision making goals (Surminski and Lopez 2014): creating awareness about the sensitivity of human and natural systems to climate change; developing risk reduction and risk management approaches to enhance adaptation, reduce vulnerability and build resilience; and informing compensation and burden sharing mechanisms.

All three require an understanding of the current and future scale and distribution of climate related L\&D. As noted above, decision makers are faced with uncertainties related to hazard, exposure and vulnerability: projections of future weather patterns from different climate models often disagree (Heal and Milner 2014), while socioeconomic trends, which influence the impact of climate change, also suffer from inherent uncertainty (IPCC 2012). For some, this may prove as a potentially welcome excuse for inaction, for others this might lead to heated, almost unresolvable disputes about the underlying science. Can this potential paralysation (Dessai et al. 2009) be avoided?

\footnotetext{
${ }^{4}$ For instance, Knutti and Sedlacek (2013) show that the projected global temperature change from the IPCC AR5 models is very similar to the one reported by the IPCC AR4 models after taking into account the different underlying scenarios. Similarly, spatial patterns of temperature and precipitation change and local model spread are also very consistent despite substantial model development. These authors argue that model improvements often imply more confidence in their projections, but do not necessarily narrow uncertainties.
} 
The ability to make L\&D decisions depends on skills and know-how for assessing the risks, and institutional capacity as well as funding to address those risks (UNFCCC 2012a). But given the large uncertainties inherent to the estimation of risk, the use of a decision-making framework that can make the best use of the available information to develop strategies to reduce L\&D is also key. Two widely recognised decision-making frameworks have been discussed in the context of CCA: the 'top down or science-driven' and the 'bottom up or policy-driven' frameworks.

In the first framework, the process starts with the generation of climate projections, often downscaled and corrected for possible biases, followed by an analysis of their physical impacts that, combined with vulnerability assessments, are used to design policies and adaptation options to mitigate those impacts. Application of the 'science-driven' approach include, for instance, the Stern Review and the IPCC risk assessments. This approach has been criticised for its heavy reliance on climate projections that are limited in their ability to represent key drivers of extreme events and not generally fit for purpose for decision support (IPCC 2012; Smith and Stern 2011; Stainforth et al. 2007), and for the potential lack of robustness of the projected impacts due to different methodological issues (Hall 2007; Merz et al. 2010; Tebaldi and Knutti 2007). Uncertainty is clearly one of the key challenges for decision-makers, especially when competing with concerns about daily lives. But the uncertainty that comes with this approach does not only stem from climate change; in fact the climate dimension just adds to the uncertainty derived from the wide range of socio-economic and environmental factors considered, often referred to as the 'cascade of uncertainty' (Schneider 1983) or the 'uncertainty explosion' (Henderson-Sellers 1993). Few science-first assessments have been used to evaluate real adaptation options, since the 'uncertainty explosion' often renders the appraisal of adaptation options impracticable (Dessai and Hulme 2007; Wilby and Dessai 2010).

The second framework starts with the adaptation problem itself rather than with climate projections. It is based on risk management approaches that begin by defining the policy or adaptation goal to be addressed (Ranger et al. 2010a, b; Willows et al. 2003). This includes delineating the objective or decision criteria, identifying present and future climatic ${ }^{5}$ and non-climatic risks that make the system vulnerable, identifying institutional and regulatory constraints, identifying the possible options,

\footnotetext{
${ }^{5}$ Modelling capabilities can be used to generate climate projections that, in combination with socioeconomic scenarios, result in suitable tools to assess vulnerabilities in different regions including, where possible, the study of vulnerability to changes in frequency of occurrence of extreme events. In the framework of scenario planning as an approach to support strategic decision-making, scenarios are intended to be challenging descriptions of a wide range of possible futures. Therefore, the combination of climate and socio-economic scenarios we refer to cannot be, by construction, representative of the full range of possible futures. On the climate modelling side for example, missing feedbacks and unknown uncertainties in climate models limit the ability to represent all plausible futures. Notwithstanding these constraints, scenarios can still be used as tools to consider a range of possible futures, and their associated consequences. Then, an analysis of the options available could be carried out, and feedback can be provided on what information about the likely futures would be most valuable for decision makers.
} 
and only then (if necessary) appraising their appropriateness against a detailed set of climate projections. In this context, the evaluation of climate risks is just one component of the estimations of all the environmental and social stressors and changes in socio-economic conditions that can induce system failures. Therefore the decision maker is encouraged to think broadly about the interactions of other risks and priorities with the adaptation problem and look for strategies that have co-benefits with other areas such as development and DRR. This approach was adopted in the Thames 2100 Estuary project (Haigh and Fisher 2010) and includes, for instance, community-based adaptation approaches.

Due to the complex, diverse, and context-dependent nature of CCA, it is currently recognised that there is no single approach to adaptation planning, with some evidence suggesting that the links between adaptation planning and implementation are strengthened when both, the science-driven and the policy-driven approaches are combined (Mimura et al. 2014).

The topic of decision-making under uncertainty has received significant attention in the context of CCA (Dessai and Hulme 2007; Gilboa 2009; Lempert 2002; Lempert and Collins 2007; Ranger et al. 2010a, b; and see McDermott 2016 and Heal and Milner 2014 for overviews). Despite the fact that in some cases reliable and robust projections are not possible (in some cases even the sign of change is not known), there are now several decision-making tools that, recognising the inherent uncertainties, are used to develop public policy, particularly in the context of adaptation and flood risk management. See Appendix 1 for an overview of some of the main tools.

Examples include adaptive management and scenario planning. Adaptive management allows for continuous modification of a policy or a strategy to take into account new learning about future trends and impacts. This involves a high degree of learning, experimenting and evaluation throughout the lifetime of the strategy or policy. Scenario planning provides decision makers with a range of different, plausible future scenarios. Policies and strategies can be tested against those scenarios to assess how they may perform. For adaptation decision-making these approaches have been developed into options analysis (Haigh and Fisher 2010; Ranger et al. 2010a, b; Dittrich et al. 2016) and portfolio analysis (Watkiss and Hunt 2016; Dittrich et al. 2016).

Real options analysis was used in the Thames 2100 Estuary project, with extensive sensitivity testing of sea level rise assumptions (i.e. incorporating some elements of robustness-based analyses) (Reeder and Ranger 2010). Gersonius et al. (2013) also applied the real options analysis to urban drainage infrastructure in West Garforth, England. 
Alternatively, decision makers can use these different scenarios to identify 'robust' strategies that would work well under most of these scenarios (Lempert and Collins 2007; Hallegatte 2009; Ranger et al. 2010a, b; Fankhauser et al. 2013; Weaver et al. 2013). Robust decision-making was applied to water supply management in California (Groves et al. 2008) and Flood risk management in Ho Chi Minh City Vietnam (Lempert et al. 2013) (see chapter by Botzen et al. 2018).

Other examples of how these strategies have been applied in different countries and sectors include the Dutch Delta Programme, the Louisiana Master Plan for a Sustainable Coast, and the Colorado River Basin Supply and Demand Study (see Lempert and Haasnoot 2017).

Even though these decision-strategies can be of value for L\&D decision-making, their application has remained relatively under-explored in this context.

In a broad sense there is clear merit in both science-driven and policy-driven approaches for L\&D decision making: scientific assessments are important for all three L\&D goals and should underpin and inform the decision process. This is particularly evident for the first L\&D goal: identifying the risks and raising awareness heavily relies on the underlying science and the socio-economic scenarios and climate and impacts models used. A top-down or science-driven approach appears most relevant for this, but the adaptation and mitigation pathways are somewhat locked by the climate scenario chosen.

However, planning any policies and measures in response will require from decision makers the need to design flexible adaptation and risk management pathways that allow for periodic adjustments as new information becomes available, and the possibility of changing to new routes when or if incremental adjustments are no longer considered sufficient according to the evidence available at the time (Hallegatte 2009; Hulme et al. 2009; Lopez et al. 2010; Wilby and Dessai 2010; Bhave et al. 2016). Moreover, the planning process will have to consider the fact that the future might involve climate change events that are not predicted, combined with unforeseen technological and societal developments. The 'policy-driven' approach encourages the use of measures that are low regret, reversible, build resilience into the system, incorporate safety margins, employ 'soft' solutions, are flexible, and deliver multiple co-benefits (Hallegatte 2009; Hulme et al. 2009). In this context the second L\&D goal shows a strong parallel with climate adaptation planning: how to minimise the climate change risk to tolerable levels, and what are the options to manage what cannot be minimised? Consequently, the challenges presented by the need to reduce and manage climate change losses and damages are not very different to the ones presented by the need to adapt to climate change and variability, and the tools described above seem adequate to address these challenges.

For the third L\&D goal of informing discussions on fair burden-sharing and compensation arrangements it is also clear that both approaches are needed. 
The estimation of precise information on attribution of damages to the incremental risk caused by anthropogenic climate change requires an estimate of the change in hazard probability that is attributable to anthropogenic climate change. From the point of view of the decision-making frameworks discussed above, this falls within the 'science-driven' approach. Climate simulations are used to estimate the likelihood of the event under current conditions, with the extra requirement of a simulation of the counterfactual world, i.e., an estimation of the likelihood of the event had greenhouse gas concentrations not increased during the last 100 years or so. Some climate scientists argue that the science of attribution of climate events could support decisions related to obtaining compensation for damages caused by attributable natural disasters, since it potentially allows to distinguish between genuine consequences of anthropogenic climate change from climate events that are a result of internal climate variability (Hoegh-Guldberg et al. 2011; Peterson et al. 2012). On the other hand, Hulme et al. (2011) challenges the idea that the science of weather event attribution has a role to play in this context, in particular due to the fact that the estimated changes in attributable risks are based on climate modelling experiments that cannot provide robust answers. However, Huggel et al. $(2015,2016)$ argue that even though attribution is not necessarily a requirement for L\&D policies, it is potentially useful for facilitating a more thematically structured, and constructive policy and justice discussion. The chapter by Wallimann-Helmer (2018) in this book discusses these issues in detail.

For the design and implementation of burden sharing or compensation instruments (technical, financial and capacity building) an estimation of the costs for managing losses and damages is needed. This would rely on a "policy-driven" approach, taking as a starting point what are the societal goals (which values to protect), and then an estimation of the resources needed to do so. Principles to distribute the burden of managing losses and damages include principles that take into consideration the causation of outcomes that need to be managed (e.g. the polluter pays principle) and principles that do not take causation into account (e.g. the ability to pay principle). The information gained through a science-driven approach can help to approximate the portion of the hazard that is of anthropogenic origin, which would inform the discussion on these compensation principles. Importantly, this information may not need to be precise or event-linked: the growing understanding of the overall likelihood of anthropogenic footprint in L\&D could be enough to justify burden-sharing, for example if big emitters recognise an overall higher responsibility to provide support than low emitters, irrespective of precise event-attribution (see also the chapter by Simlinger and Mayer (2018) on legal issues). 


\subsection{Conclusions}

The different dimensions of L\&D of climate change make this a complex topic, with a range of interpretations, approaches and responses being considered, while the political negotiations are in full flow. Reflecting on the current state of discussion we draw the following conclusions.

To date there are no easy answers to the L\&D challenges. This is not only due to technical and science limitations, but also due to the political dimension and the uncertainties inherent in this process.

L\&D of climate change remains a political concept, developed during the UNFCCC negotiations (see chapter by Calliari et al. 2018), but with its technical roots in CCA and DRR. The 2015 Paris Agreement of the UNFCCC recognises "the importance of averting, minimizing and addressing Loss and Damage associated with the adverse effects of climate change, including extreme weather events and slow onset events" (UNFCCC 2015). This aligns with three goals embedded in the L\&D discussion:

- To create awareness about the sensitivity of human and natural systems to climate, and the need to respond with appropriate mitigation, adaptation and DRR policies.

- To plan risk reduction and risk management, with the goal to enhance adaptation to reduce vulnerability and build resilience.

- To inform burden sharing for the costs of managing L\&D and compensation arrangements.

Clearly, existing tools and approaches from the fields of CCA and DRR can help responding to $\mathrm{L} \& \mathrm{D}$.

The first two goals are common to the CCA and DRR discussions, and lessons learnt in those areas can be shared here. The lack of data and knowledge should not be seen as a reason for delaying action-in fact there are a range of existing instruments and tools that can be applied to assess and manage current and future L\&D. As described above, within the CCA community, tools and approaches have recently been developed to deal with uncertainty from climate science in order to avoid a 'wait and see' mentality for decision making. In this context, the challenges presented by the need to reduce and manage climate change losses and damages are not very different to the ones presented by the need to adapt to climate change and variability.

The compensation component of L\&D, however, offers a different dimension to the climate change discussion. While not explicitly outlined in the official UNFCCC language, this is an underlying aim that has been driving the L\&D debate since its beginnings. The focus on compensation for those climate impacts that are beyond mitigation and adaptation's reach poses some additional challenges for decision makers-particularly in the context of the underlying science, as seen in the discussion of attribution (see also chapter by James et al. 2018 in this book).

Importantly, the majority of climate change experts (as reflected by the last chapters of IPCC 2012) seem to have come to the conclusion that the only way to deal with 
climate change is to take a holistic approach to risk management, using a wide range of approaches to evaluate expected risks and benefits (IPCC 2014a, b). This therefore underlines the importance of comprehensive approaches, incorporating hazard, vulnerability and exposure elements of risk. It also opens up the question of the specific role of L\&D under the United Nations Framework Convention on Climate Change, alongside the institutional set up for adaptation under the UNFCCC and for DRR under UNISDR's Sendai Framework. As there are many thematic and technical overlaps between these areas, it is important for those bodies administering this at the UN level to recognize the synergies and avoid duplication. This also applies to other governance levels, from national to local, where far too often disaster risk management and climate adaptation are kept institutionally apart.

Overall, the physical sciences play a key role in informing all aspects of climate change L\&D discussions. Climate data is important throughout, while there are some clear shortcomings in terms of accessibility, availability and quality of it. The recognition of limitations and uncertainties in this information is important, particularly for those who will make decisions around L\&D. The recognition of these limitations should also extend to the information on exposure and vulnerability, which plays a significant role in determining the eventual losses and damages. Progress is being made with regards to loss assessments and accounting for indirect consequences as well as estimating socio-economic risk drivers (IPCC 2012).

However, the idea of L\&D for compensation and burden sharing might trigger increased efforts to dissect the human induced climate change part of the risk. Informing the discussions on how to share the costs for managing L\&D relies on two separate steps: (1) estimating the costs of managing L\&D, and (2) informing the causationbased principles of the debate. Clearly, the caveats and scientific challenges of attribution that have been outlined here need to be part of such discussions. However, this should not put on hold the efforts to integrate adaptation to climate change with wider development aims and disaster risk reduction, and the search for innovative approaches to share the financial burden of current and future losses and damages. 


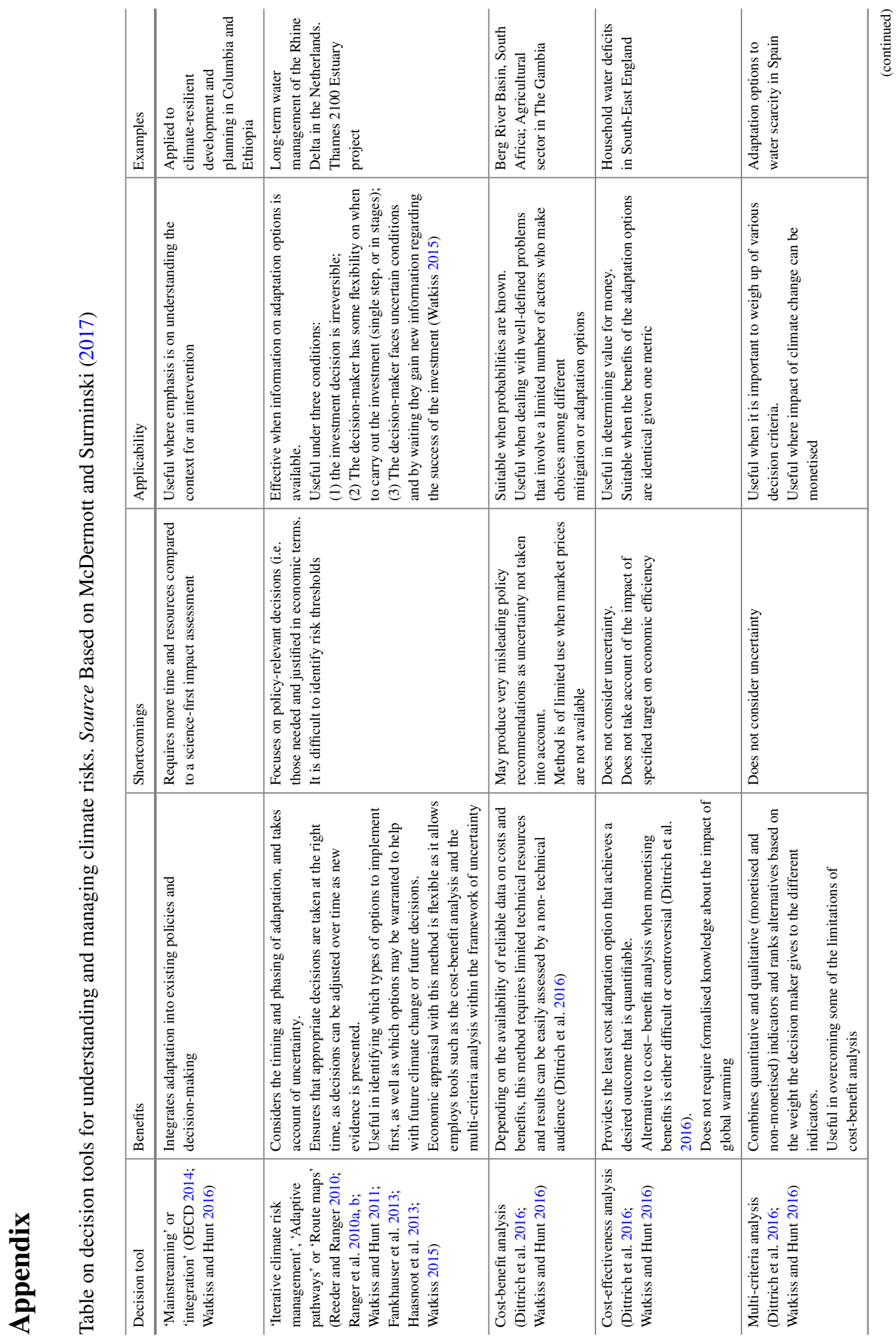




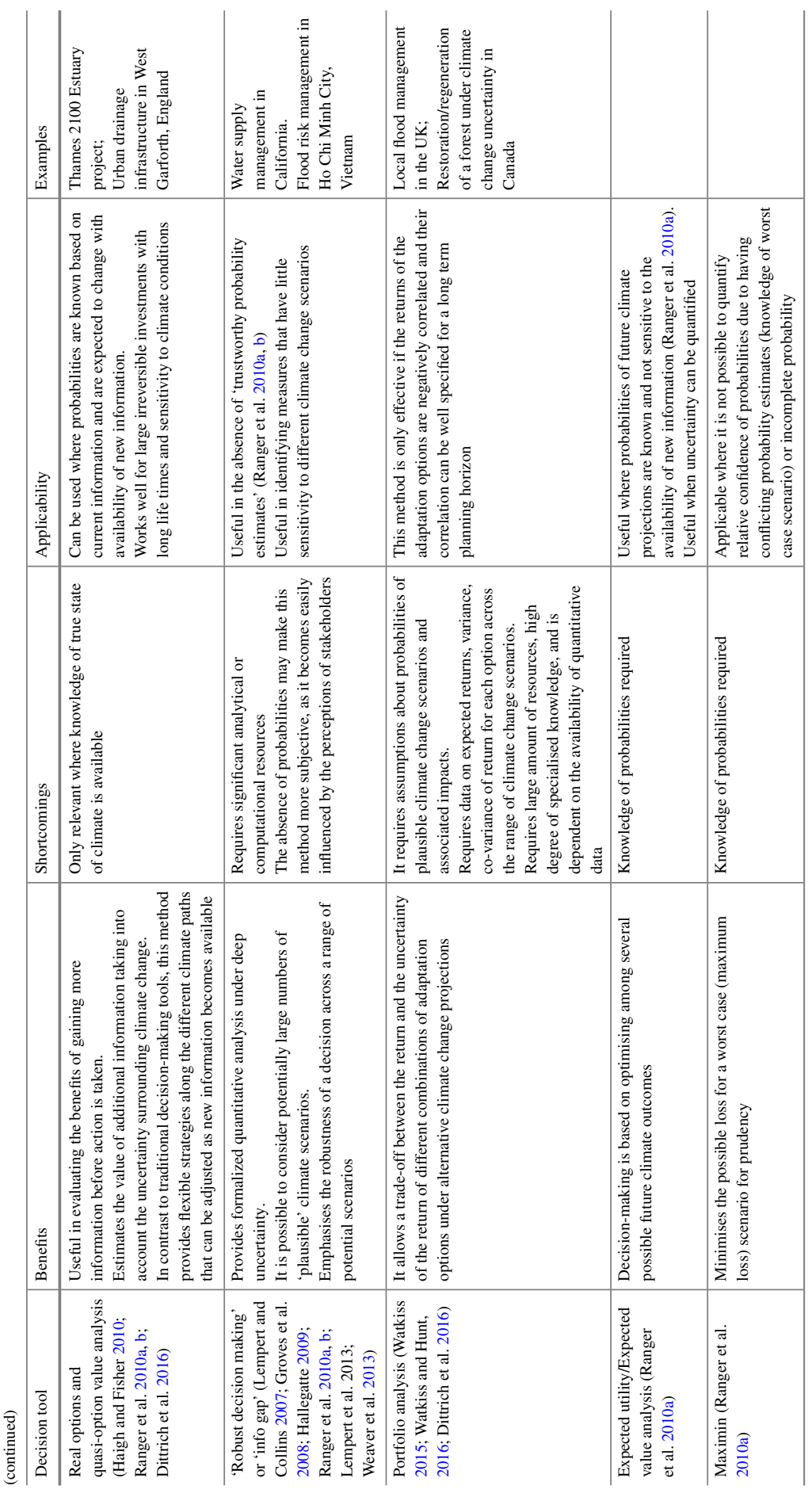




\section{References}

Bellprat O, Doblas-Reyes F (2016) Unreliable climate simulations overestimate attributable risk of extreme weather and climate events. Geophys Res Lett 43:2158-2164. https://doi.org/10.1002/2 $015 \mathrm{~g} 1067189$

Benito G, Lang M, Barriendos M, Llasat MC, Francés F, Ouarda T, Varyl R, Thorndycraft VR, Enzel Y, Bardossy A, Coeur D, Bobée B (2004) Use of systematic, palaeoflood and historical data for the improvement of flood risk estimation. Review of scientific methods. Nat Hazards 31:623-643. https://doi.org/10.1023/B:NHAZ.0000024895.48463.eb

Bhave AG, Conway D, Dessai S, Stainsforth DA (2016) Barriers and opportunities for robust decision making approaches to support climate change adaption in the developing world. Clim Risk Management 14:1-10. https://doi.org/10.1016/j.crm.2016.09.004

Booth BBB, Bernie D, McNeall D, Hawkins E, Caesar J, Boulton C, Friedlingstein P, Sexton DMH (2013) Scenario and modelling uncertainty in global mean temperature change derived from emission-driven global climate models. Earth Sys Dyn 4:95-108. https://doi.org/10.5194/esd-495-2013

Bos SPM, Pagella T, Kindt R, Russell AJM, Luedeling E (2015) Climate analogs for agricultural impact projection and adaptation—reliability test. Front Environ Sci. https://doi.org/10.3389/fe nvs.2015.00065. Accessed 30 Jan 2016

Botzen W, Bouwer LM, Scussolini P, Kuik O, Haasnoot M, Lawrence J, Aerts JCJH (2018) Integrated disaster risk management and adaptation. In: Mechler R, Bouwer L, Schinko T, Surminski $\mathrm{S}$, Linnerooth-Bayer J (eds) Loss and damage from climate change. Concepts, methods and policy options. Springer, Cham, pp 287-315

Bouwer LM (2018) Observed and projected impacts from extreme weather events: implications for loss and damage. In: Mechler R, Bouwer L, Schinko T, Surminski S, Linnerooth-Bayer J (eds) Loss and damage from climate change. Concepts, methods and policy options. Springer, Cham, pp 63-82

Calliari E, Surminski S, Mysiak J (2018) The politics of (and behind) the UNFCCC's loss and damage mechanism. In: Mechler R, Bouwer L, Schinko T, Surminski S, Linnerooth-Bayer J (eds) Loss and damage from climate change. Concepts, methods and policy options. Springer, Cham, pp 155-178

Dahinden F, Fischer EM, Knutti R (2017) Future local climate unlike currently observed anywhere. Environ Res Lett 12. https://doi.org/10.1088/1748-9326/aa75d7. Accessed 20 Jul 2017

Dankers R, Arnell NW, Clark DB, Falloon PD, Fekete BM, Gosling SN, Heinke J, Kim H, Masaki Y, Satoh Y, Stacke T, Wada Y, Wisser D (2014) First look at changes in flood hazard in the intersectoral impact model intercomparison project ensemble. PNAS 111 (9)3257-3261. https://doi. org/10.1073/pnas.1302078110

Deser C, Phillips A, Bourdette V, Teng H (2012a) Uncertainty in climate change projections: the role of internal variability. Clim Dyn 38:527-546

Deser C, Knutti R, Solomon S, Phillips AS (2012b) Communication of the role of natural variability in future North American climate. Nat Clim Change 2:775-779

Dessai S, Hulme M (2007) Assessing the robustness of adaptation decisions to climate change uncertainties: a case study on water resources management in the East of England. Glob Environ Change 17(1):59-72

Dessai S, Hulme M, Lempert R, Jr Pielke (2009) Do we need better predictions to adapt to a changing climate? Eos, Trans Am Geophys Union 90(13):112-113. https://doi.org/10.1029/200 9EO130003

Dittrich R, Wreford A, Moran D (2016) A survey of decision-making approaches for climate change adaptation: Are robust methods the way forward? Ecol Econ 122:79-89

Fankhauser S, Ranger N, Colmer J (2013) An independent national adaptation programme for England. Policy brief. Grantham Research Institute on Climate Change and the Environment, London School of Economics 
GAR (2011) UNISDR: global assessment report on disaster risk reduction. Switzerland, Geneva, p 2011

Gersonius B, Ashley R, Pathirana A, Zevenbergen C (2013) Climate change uncertainty: building flexibility into water and flood risk infrastructure. Clim Change 116:411-423

Gilboa I (2009) Theory of decision under uncertainty, 1st edn. Cambridge University Press, Cambridge, UK

Giorgi F, Gutowski WJ Jr (2015) Regional dynamical downscaling and the CORDEX initiative. Annu Rev Environ Resour 40:467-490. https://doi.org/10.1146/annurev-environ-10 2014-021217

Groves DG, Lempert RJ, Knopman D, Berry SH (2008) Preparing for an uncertain future climate in the Inland empire: identifying robust water-management strategies. Rand Corporation, USA

Haigh N, Fisher J (2010) Using a "Real Options" approach to determine a future strategic plan for flood risk management in the Thames Estuary. Draft Government Economic Service Working Paper

Hall A (2014) Projecting regional change. Science 346(6216):1461-1462

Hall J (2007) Probabilistic climate scenarios may misrepresent uncertainty and lead to bad adaptation decisions. Hydrol Process 21:1127-1129. https://doi.org/10.1002/hyp.6573

Hallegatte S (2009) Strategies to adapt to an uncertain climate change. Glob Environ Change 19:240-247. https://doi.org/10.1016/j.gloenvcha.2008.12.003

Haasnoot M, Kwakkel JH, Walker WE, ter Maar J (2013) Dynamic adaptive policy pathways: a method for crafting robust decisions for a deeply uncertain world. Global Env. Change 23(485):498

Hawkins E, Sutton R (2009) The potential to narrow uncertainty in regional climate predictions. Bull Am Meteor Soc 90:1095-1107. https://doi.org/10.1175/2009BAMS2607.1

Heal G, Millner A (2014) Uncertainty and decision making in climate change economics. Rev Environ Econ Policy 8(1):120-137

Henderson-Sellers A (1993) An Antipodean climate of uncertainty. Clim Change 25(3-4):203-224. https://doi.org/10.1007/BF01098373

Hewitson B, Janetos AC, Carter TR, Giorgi F, Jones RG, Kwon W-T, Mearns LO, Schipper ELF, van Aalst M (2014) Regional context. In: Barros VR, CB Field DJ, Dokken MD, Mastrandrea KJ, Mach TE, Bilir M, Chatterjee KL, Ebi YO, Estrada RC, Genova B, Girma ES, Kissel AN, Levy S, MacCracken PR, Mastrandrea LL White (eds) Climate change 2014: impacts, adaptation, and vulnerability. Part B: regional aspects. Contribution of working group II to the fifth assessment report of the intergovernmental panel on climate change. Cambridge University Press, Cambridge, United Kingdom and New York, NY, USA, pp 1133-1197

Hoegh-Guldberg O, Hegerl G, Root T, Zwiers F, Stott P, Pierce D, Allen M (2011) Difficult but not impossible. Nat Clim Change 1:72. https://doi.org/10.1038/nclimate1107

Huggel C, Stone D, Eicken H, Hansen G (2015) Potential and limitations of the attribution of climate change impacts for informing loss and damage discussions and policies. Clim Change. https://d oi.org/10.1007/s10584-015-1441-z

Huggel C, Wallimann-Helmer I, Stone D, Cramer W (2016) Nat Clim Change 6:901-908. https:// doi.org/10.1038/nclimate3104

Hulme M, Pielke R, Dessai S (2009) Keeping prediction in perspective. Nature 3:126-127. https:// doi.org/10.1038/climate.2009.110

Hulme M, Neil O', Dessai S (2011) Is weather event attribution necessary for adaptation funding? Nature 334(6057):764-765. https://doi.org/10.1126/science.1211740

IPCC Nakicenovic N, Swart R (eds) (2000) Special report on emissions scenarios. Cambridge University Press, Cambridge, UK, p 570

IPCC Field CB, Barros V, Stocker TF, Qin D, Dokken DJ, Ebi KL, Mastrandrea MD, Mach KJ, Plattner G-K, Allen SK, Tignor M, Midgley PM (eds) (2012), Managing the risks of extreme events and disasters to advance climate change adaptation. A special report of working groups I and II of the intergovernmental panel on climate change. Cambridge University Press, Cambridge, UK, and New York, NY, USA, 582 pp 
IPCC Stocker TF, Qin D, Plattner G-K, Tignor M, Allen SK, Boschung J, Nauels A, Xia Y, Bex V, Midgley PM (eds) (2013) Climate change 2013: the physical science basis. Contribution of working group I to the fifth assessment report of the intergovernmental panel on climate change. Cambridge University Press, Cambridge, United Kingdom and New York, NY, USA, 1535 pp

IPCC Field CB, Barros VR, Dokken DJ, Mach KJ, Mastrandrea MD, Bilir TE, Chatterjee M, Ebi KL, Estrada YO, Genova RC, Girma B, Kissel ES, Levy AN, MacCracken S, Mastrandrea PR, White LL (eds) (2014a) Climate change 2014: impacts, adaptation, and vulnerability. Part A: global and sectoral aspects. contribution of working group II to the fifth assessment report of the intergovernmental panel on climate change. Cambridge University Press, Cambridge, United Kingdom and New York, NY, USA, 1132 pp

IPCC Barros VR., Field CB, Dokken DJ, Mastrandrea MD, Mach KJ, Bilir TE, Chatterjee M, Ebi KL, Estrada YO, Genova RC, Girma B, Kissel ES, Levy AN, MacCracken S, Mastrandrea PR, White LL (eds) (2014b) Climate change 2014: impacts, adaptation, and vulnerability. Part B: regional aspects. Contribution of working group II to the fifth assessment report of the intergovernmental panel on climate change. Cambridge University Press, Cambridge, United Kingdom and New York, NY, USA, pp. 688

James RA, Jones RG, Boyd E, Young HR, Otto FEL, Huggel C, Fuglestvedt JS (2018) Attribution: how is it relevant for loss and damage policy and practice? In Mechler R, Bouwer L, Schinko T, Surminski S, Linnerooth-Bayer J (eds) Loss and damage from climate change. Concepts, methods and policy options. Springer, Cham, pp 113-154

Jha AK, Bloch R, Lamond J (2012) Cities and flooding: a guide to integrated urban flood risk management for the 21st Century. World Bank. https://openknowledge.worldbank.org/handle/1 0986/2241. License: CC BY 3.0 IGO Accessed 23 Jan 2013

Kerr RA (2011) Vital details of global warming are eluding forecasters. Science 334(6053):173-174. https://doi.org/10.1126/science.334.6053.173

Kirtman B, Power SB, Adedoyin JA, Boer GJ, Bojariu R, Camilloni I, Doblas-Reyes FJ, Fiore AM, Kimoto M, Meehl GA, Prather M, Sarr A, Schär C, Sutton R, van Oldenborgh GJ, Vecchi G, Wang HJ (2013) Near-term climate change: projections and predictability. In: Stocker TF, Qin D, Plattner G-K, Tignor M, Allen SK, Boschung J, Nauels A, Xia Y, Bex V, Midgley PM (eds) Climate change 2013: the physical science basis. Contribution of working group I to the fifth assessment report of the intergovernmental panel on climate change. Cambridge University Press, Cambridge, United Kingdom and New York, NY, USA

Klein RJT, Huq S, Denton F, Downing TE, Richels RG, Robinson JB, Toth FL (2007) Interrelationships between adaptation and mitigation. In: Parry ML, Canziani OF, Palutikof JP, van der Linden PJ, Hanson CE (eds) Climate change 2007: impacts, adaptation and vulnerability. Contribution of working group II to the fourth assessment report of the intergovernmental panel on climate change. Cambridge University Press, Cambridge, UK, pp 745-777

Knutti R, Allen MR, Friedlingstein P, Gregory JM, Hegerl GC, Meehl GA, Meinshausen M, Murphy JM, Plattner GK, Raper SCB, Stocker TF, Stott PA, Teng H, Wigley TML (2007) A review of uncertainties in global temperature projections over the twenty-first century. J Clim 21:2651. https://doi.org/10.1175/2007JCLI2119.1

Knutti R, Sedlacek J (2013) Robustness and uncertainties in the new CMIP5 climate model projections. Nat Clim Change 3:369-373. https://doi.org/10.1038/nclimate1716

Kreft S (2012) Loss \& damage overview and summary of party submissions on the role of the convention. A Germanwatch e. V. Paper. http://www.loss-and-damage.net/download/6868.pdf Accessed 29 Jan 2012

Lempert RJ (2002) A new decision sciences for complex systems. Proc Natl Acad Sci 99(10), supp. 3:7309-7313. https://doi.org/10.1073/pnas.082081699

Lempert RJ, Collins MT (2007) Managing the risk of uncertain threshold responses: comparison of robust, optimum, and precautionary approaches. Risk Anal 27(4):1009-1026. https://doi.org/ 10.1111/j.1539-6924.2007.00940.x

Lempert RJ, Haasnoot M (2017) Decision-making under uncertain climate change: a response, and an invitation, to Bret Stephens, in Society for Decision Making Under Deep Uncertainty 
Blog. http://www.deepuncertainty.org/2017/05/09/decision-making-under-uncertain-climate-ch ange-a-response-and-an-invitation-to-bret-stephens/. Accessed 10 May 2017

Lempert RJ, Kalra N, Peyraud S, Mao Z, Tan SB, Cira D, Lotsch A (2013) Ensuring robust flood risk management in Ho Chi Minh City, Policy Research Working Paper 6465, The World Bank. https://doi.org/10.1596/1813-9450-6465

Lopez A, Wilby RL, Fung F, New M (2010) Emerging approaches to climate risk management. In: Fung F., Lopez A, New M (eds) Modelling the impacts of climate change in water resources, Wiley \& Sons, Ltd, Chichester, UK. https://doi.org/10.1002/9781444324921.ch5

McDermott TKJ (2016) Investing in disaster risk management in an uncertain climate, World Bank Policy Research Working Paper, WPS7631

McDermott TKJ, Surminski S (2017) How to make climate science useful for the decision-making process? Experiences from the local city-level, forthcoming

Mechler R, Hochrainer S, Kull D, Khan F, Patnaik U, Linnerooth-Bayer J (2009) Increasing resilience to extreme events Options (IIASA, Laxenburg, Austria). http://webarchive.iiasa.ac. at/Admin/PUB/Documents/XO-09-076.pdf. Accessed 12 Feb 2012

Mechler R et al (2018) Science for Loss and damage. Findings and propositions. In: Mechler R, Bouwer L, Schinko T, Surminski S, Linnerooth-Bayer J (eds) Loss and damage from climate change. Concepts, methods and policy options. Springer, Cham, pp 3-37

Meinshausen M, Smith SJ, Calvin K, Daniel JS, Kainuma LT, Lamarque J-F, Matsumoto K, Montzka SA, Raper SCB, Riahi K, Thomson A, Velders GJM, van Vuuren DPP (2011) The RCP greenhouse gas concentrations and their extensions from 1765 to 2003. Clim Change 109:213. https://doi.or $\mathrm{g} / 10.1007 / \mathrm{s} 10584-011-0156-\mathrm{z}$

Merz B, Hall J, Disse M, Schumann A (2010) Fluvial flood risk management in a changing world. Nat Hazards Earth Sys Sci 10:509-527. https://doi.org/10.5194/nhess-10-509-2010

Mimura N, Pulwarty RS, Duc DM, Elshinnawy I, Redsteer MH, Huang HQ, Nkem JN, Sanchez Rodriguez RA (2014) Adaptation planning and implementation. In ref IPCC (2014a)

Moss RH, Babiker WM, Brinkman S, Calvo SE, Carter TR, Edmonds J, Elgizouli I, Emori S, Erda L, Hibbard K, Jones R, Kainuma M, Kellehe J, Lamarque JF, Manning M, Matthews B, Meehl J, Meyer L, Mitchell J, Nakicenovic N, O’Neill B, Pichs R, Riahi K, Rose S, Runci P, Stouffer R, van Vuuren D, Weyant J, Wilbanks T, van Ypersele JP, Zurek M (2008) Towards new scenarios for analysis of emissions, climate change, impacts, and response strategies, Intergovernmental Panel on Climate Change, Geneva, Switzerland, pp 132

OECD (2014) Cities and climate change: national governments enabling local action. OECD

Oppenheimer M, Campos M, Warren R, Birkmann J, Luber G, O’Neill B, Takahashi K (2014) Emergent risks and key vulnerabilities. In: Field CB, Barros VR, Dokken DJ, Mach KJ, Mastrandrea MD, Bilir TE, Chatterjee M, Ebi KL, Estrada YO, Genova RC, Girma B, Kissel ES, Levy AN, MacCracken S, Mastrandrea PR, White LL (eds) Climate change 2014: impacts, adaptation, and vulnerability. Part A: global and sectoral aspects. Contribution of working group II to the fifth assessment report of the intergovernmental panel on climate change. Cambridge University Press, Cambridge, United Kingdom and New York, NY, USA, pp 1039-1099

Oreskes N, Stainsforth DA, Smith LA (2010) Adaptation to global warming: do climate models tell us what we need to know? Philos Sci 77(5):1012-1028. https://doi.org/10.1086/657428

Peterson TC, Stott PA, Herring S (2012) Explaining extreme events of 2011 from a climate perspective, Bull Am Meteor Soc 93(7):041-1061. https://doi.org/10.1175/BAMS-D-12-00021.1

Ranger N, Hallegatte S, Bhattacharya S, Bachu M, Priya S, Dhore K, Rafique F, Mathur P, Naville N, Henriet F, Herweijer C, Pohit S, Corfee-Morlot J (2011) A preliminary assessment of the potential impact of climate change on flood risk in Mumbai. Clim Change 104:139-167. https:// doi.org/10.1007/s10584-010-9979-2

Ranger N, Millner A, Dietz S, Fankhauser S, Lopez A, Ruta G (2010a) Adaptation in the UK: a decision making process, Grantham/CCCEP Policy Brief. http://www2.lse.ac.uk/GranthamInsti tute/publications/Policy/docs/PB-Ranger-adaptation-UK.pdf. Accessed 29 Jan 2013 
Ranger N, Millner A, Lopez A, Ruta G, Hardiman A (2010b) Adaptation in the UK: a decision making process: technical annexes. http://www2.1se.ac.uk/GranthamInstitute/publications/Polic y/docs/PB-technical-annexes-rangeretal.pdf. Accessed 29 Jan 2013

Reeder T, Ranger N (2010) How do you adapt in an uncertain world? Lessons from the Thames Estuary 2100 project. World Resources Report, Washington DC

Risby JS, O' Kane TJ (2011) Sources of knowledge and ignorance in climate research. Clim Change 108(4):755-773. https://doi.org/10.1007/s10584-011-0186-6

Schellnhuber HJ, Frieler K, Kabat P (2014) The elephant, the blind, and the intersectoral inter-comparison of climate impacts. PNAS 111:3225-3227. https://doi.org/10.1073/pnas.132 1791111

Schewe J, Heinke J, Gerten D, Haddeland I, Arnell NW, Clark DB, Dankers R, Eisner S, Fekete BM, Colón-González FJ, Gosling SN, Kim H, Liu X, Masaki Y, Portmann FT, Satoh Y, Stacke T, Tang O, Wada Y, Wisser D, Albrecht T, Frieler K, Piontek F, Warszawski L, Kabat P (2014) Multimodel assessment of water scarcity under climate change. PNAS 111(9):3245-3250. https:// doi.org/10.1073/pnas.1222460110

Schinko T, Mechler R, Hochrainer-Stigler S (2018) The risk and policy space for loss and damage: integrating notions of distributive and compensatory justice with comprehensive climate risk management. In: Mechler R, Bouwer L, Schinko T, Surminski S, Linnerooth-Bayer J (eds) Loss and damage from climate change. Concepts, methods and policy options. Springer, Cham, pp 83-110

Schneider SH (1983) $\mathrm{CO}_{2}$, climate and society: a brief overview. In: Chen RS, Boulding E, Schneider $\mathrm{SH}$ (eds) Social science research and climate change: an interdisciplinary appraisal. Reidel, D., Boston, MA, USA, pp 9-15

Simlinger F, Mayer B (2018) Legal responses to climate change induced loss and damage. In: Mechler R, Bouwer L, Schinko T, Surminski S, Linnerooth-Bayer J (eds) Loss and damage from climate change. Concepts, methods and policy options. Springer, Cham, pp 179-203

Smit B, Burton I, Klein RJT, Wandel J (2000) An anatomy of climate change and variability. Clim Change 45:223-251, and references therein. https://doi.org/10.1007/978-94-017-3010-5_12

Smith LA, Stern N (2011) Uncertainty in science and its role in climate policy. Trans R Soc London A: Math Phys Eng Sci 369(1956):4818-4841. https://doi.org/10.1098/rsta.2011.0149

Smithers J, Smit B (1997) Human adaptation to climatic variability and change. Glob Environ Change 7:129-146. https://doi.org/10.1016/S0959-3780(97)00003-4

Stainforth DA, Allen MR, Tredger ER, Smith LA (2007) Confidence, uncertainty and decisionsupport relevance in climate predictions. Philos Trans R Soc London A: Math Phys Eng Sci 365(1857):2145-2161. https://doi.org/10.1098/rsta.2007.2074

Stott PA, Karoly DJ, Zwiers FF (2017) Is the choice of statistical paradigm critical in extreme event attribution studies? Clim Change. https://doi.org/10.1007/s10584-017-2049-2

Surminski S, Lopez A (2014) Concept of loss and damage of climate change-a new challenge for climate decision-making? A climate science perspective. Clim Dev 7:267-277

Tebaldi C, Knutti R (2007) The use of multi-model ensemble in probabilistic climate projections. Philos Trans R Soc London A: Math Phys Eng Sci 365(1857):2053-2075. https://doi.org/10.10 98/rsta.2007.2076

Trenberth KE (2012) Framing the way to relate climate extremes to climate change. Clim Change 115:283-290. https://doi.org/10.1007/s10584-012-0441-5

Trenberth KE, Fasullo JT (2012) Climate extremes and climate change: The Russian heat wave and other climate extremes of 2010. J Geophys Res: Atmos 117:D17103. https://doi.org/10.1029/20 12JD018020

UNFCCC (2008) Compendium on methods and tools to evaluate impacts of, and vulnerability and adaptation to climate change. UNFCCC Secretariat. http://unfccc.int/files/adaptation/nairobi_w orkprogramme/compendium_on_methods_tools/application/pdf/20080307_compendium_m_t_ complete.pdf. Accessed 16 Feb 2014

UNFCCC (2012a) Current knowledge on relevant methodologies and data requirements as well as lessons learned and gaps identified at different levels, in assessing the risk of loss and damage 
associated with the adverse effects of climate change. United Nations Framework Convention on Climate Change (UNFCCC). Technical paper, FCCC/TP/2012/1. http://unfccc.int/resource/doc s/2012/tp/01.pdf. Accessed 23 Jan 2013

UNFCCC (2012b) Report on the expert meeting on assessing the risk of loss and damage associated with the adverse effects of climate change. United Nations Framework Convention on Climate Change (UNFCCC). Subsidiary Body for Implementation (SBI), FCCC/SBI/2012/INF.3. http:// unfccc.int/resource/docs/2012/sbi/eng/inf03.pdf. Accessed 29 Jan 2012

UNFCCC (2015) Paris Agreement. FCCC/CP/2015/L.9/Rev.1 https://unfccc.int/resource/docs/20 15/cop21/eng/109r01.pdf. Accessed 24 May 2016

van Vuuren DP, Isaac M, Kundzewicz ZW, Arnell N, Barker T, Criqui P Hilderink H, Hinkel J, Hof A, Kitous A, Kram T, Mechler R, Scrieciu S (2011) The use of scenarios as the basis for combined assessment of climate change mitigation and adaptation. Global Environ Change 21(2):575-591. [N/A]. https://doi.org/10.1016/j.gloenvcha.20https://doi.org/10.11.003

Wallimann-Helmer I, Meyer L, Mintz-Woo K, Schinko T, Serdeczny O (2018) The ethical challenges in the context of climate loss and damage. In: Mechler R, Bouwer L, Schinko T, Surminski S, Linnerooth-Bayer J (eds) Loss and damage from climate change. Concepts, methods and policy options. Springer, Cham, pp 39-62

Watkiss P (2015) A review of the economics of adaptation and climate-resilient development. Centre for Climate Change Economics and Policy Working Paper No. 231, Grantham Research Institute on Climate Change and the Environment Working Paper No. 205

Watkiss P, Hunt A (2011) Method for the UK Adaptation Economic Assessment (Economics of Climate Resilience). Final Report to Defra. May. Deliverable 2.2.1

Watkiss P, Hunt A (2016) Assessing climate-resilient development options. In: Fankhauser S, McDermott TKJ (eds) the economics of climate-resilient development. Edward Elgar, Massachusetts, pp 99-124

Weaver CPRJ, Lempert RJ, Brown C (2013) Improving the contribution of climate model information to decision making: the value and demands of robust decision frameworks. Wiley Interdisc Rev: Clim Change 4(1):39-60. https://doi.org/10.1002/wcc.202

Weisheimer A, Schaller N, O'Reilly C, MacLeod AA, Palmer T (2017) Atmospheric seasonal forecasts of the twentieth century: multi-decadal variability in predictive skill of the winter North Atlantic Oscillation (NAO) and their potential value for extreme attribution. Q J R Meteorol Soc. https://doi.org/10.1002/qj.2976

Wilby RL, Dessai S (2010) Robust adaptation to climate change. Weather 65(7):180-185. https:// doi.org/10.1002/wea.543

Wilby RL, Troni J, Biot Y, Tedd L, Hewitson BC, Smith DM, Sutton RT (2009) A review of climate risk information for adaptation and development planning. Int J Climatol 29(9):1193-1215. https://doi.org/10.1002/joc1839

Willows R, Reynard N, Meadowcroft I, Connell R (2003) Climate adaptation: risk, uncertainty and decision-making, Technical Report. In: Willows, RI, Connell RK (eds) UKCIP, Oxford, UK 
Open Access This chapter is licensed under the terms of the Creative Commons Attribution 4.0 International License (http://creativecommons.org/licenses/by/4.0/), which permits use, sharing, adaptation, distribution and reproduction in any medium or format, as long as you give appropriate credit to the original author(s) and the source, provide a link to the Creative Commons license and indicate if changes were made.

The images or other third party material in this chapter are included in the chapter's Creative Commons license, unless indicated otherwise in a credit line to the material. If material is not included in the chapter's Creative Commons license and your intended use is not permitted by statutory regulation or exceeds the permitted use, you will need to obtain permission directly from the copyright holder.

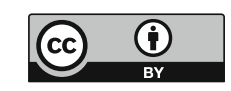

